\title{
Study of Climate Change using GCM Downscaling: Special Reference to Indian Subcontinent
}

\author{
Narayan P. Gautam and Manohar Arora
}

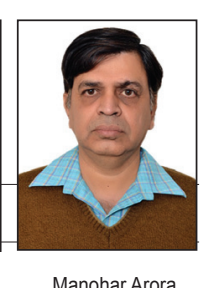

Abstract: Climate change refers to a change in a state of the climate and it is one of the emerging issues in the 21 st century. General Circulation Model (GCM) represents physical processes in the atmosphere, ocean, cryosphere and land surface. It is one of the advanced tools for simulating the response of the global climate system to increasing greenhouse gas (GHG) concentrations. The application of GCMs and its downscaling outputs helps to fill up the gap existing between large-scale and local-scale variables. This study clearly showed that GCM downscaling has been increasingly applied to the study of climate change in many parts of the world including the Indian sub-continent and their results are utilized to enhance planning and management purposes.

Keywords: Climate change, general circulation model, greenhouse gas, downscaling

\section{Introduction}

Climate is the statistical description in terms of the mean and variability of relevant quantities over a period of time ranging from months to thousands or millions of years (IPCC 2008). Climate is one of the key parameters in the earth's environment and is greatly responsible for the overall conditions for the survival of living beings at a particular place. The conditions for non-living beings are also affected by the existing climate availed in the region.

Climate change refers to a change in the state of the climate that can be identified by changes in the mean and/or the variability of its properties and that persists for an extended period, typically decades or longer (Gautam 2014). Anthropogenic factors are crucial reasons to intensify climatic changes. Human activities that could possibly change the climate include emission of gases into the atmosphere, industrial activities, development of extensive cities, pollution of water ways and cities, creation of thousands of dams and lakes, conversion of grassland or forest to cropland, agricultural activities (Piechota and Garbrecht 2006).

It is a fact that the climate in the earth is dynamic and always changing through a natural cycle. In earlier periods, it was assumed that climate change mainly occur due to natural causes. Some of the natural causes such as continental drift, volcanoes, the earth's tilt and ocean currents contribute to climate change. In the present context, by analyzing results obtained from climatic models, anthropogenic reasons are said to be the most important factor to aggravate climate change in the world. Due to the reason, scientists have agreed to reduce emission of greenhouse gases (GHGs) in the world and Kyoto protocol is one of the examples of agreement on it.

Solomon et al. (2007) concluded that continuous greenhouse gas emissions at or above current rates will cause further warming and induce many changes in the global climate system during the twenty first century that would very likely be larger than those observed during the twentieth century.
Beyond the concept of GHGs, a group of scientists proposed another concept that "land-use change impacts regional and global climate through the surface-energy budget, as well as through carboncycle effects" (Sr. Pielke et al. 2002). They also argued that the effects of the surface-energy budget may be more important than carbon cycle effects.

Global warming is considered as a major factor causing climate change. The average global temperature rose by 0.74 oC over the last hundred years (1906-2005), with more than half of this rise, or $0.44 \mathrm{oC}$, in the last 25 years (ICIMOD 2009).

IPCC (2001) has indicated that variability in Asian summer monsoon is expected to increase along with changes in the frequency and intensity of extreme climate events in this region. All climate models simulate an enhanced hydrological cycle and increases in annual mean rainfall over South Asia (under nonaerosol forcing).

\section{Significance of this Study}

It is a fact that research on climate change is one of the highly useful methodologies to understand the reality of the climatic condition at a particular place whether it is at global level or local level. The predicted future climatic condition will be greatly useful to scientifically improve the matters related to planning, decision making systems, etc. In the past, very few scientific works relating to climate change by General Circulation Model (GCM) have been carried out in South Asian region. This study has focused on signifying the importance of GCM in climatic analysis for Indian subcontinent.

\section{General Circulation Model (GCM)}

General Circulation Models (GCMs) are also known by the name of global climate models. According to the Inter-governmental Panel on Climate Change (IPCC), GCMs reproduce physical processes in the atmosphere, ocean, cryosphere and land surface. They are one of the most advanced tools currently available for simulating the response of the global climate 
system to increase in greenhouse gas concentrations. They are capable of providing geographically and physically consistent estimates of regional climate change, which are required in impact analysis. The atmospheric or oceanic GCMs (AGCM or OGCM) are key components of GCMs which include land-surface, sea-ice and ocean components.

GCMs illustrate the climate, using a three dimensional grid over the globe having a horizontal resolution of between 250 and $600 \mathrm{~km}, 10$ to 20 vertical layers in the atmosphere and sometimes as many as 30 layers in the oceans (IPCC 2009). However, some sub-grid scale features like clouds and topography at smaller scale cannot be properly modeled by GCMs due to their coarse spatial resolutions of the order of 50,000 sq. km (Wilby et al. 2004).

There are several GCMs currently in operation in different countries of the world. Table 1 lists some of the GCMs and the countries operating them.

\begin{tabular}{|c|c|}
\hline GCMs & Institution and country \\
\hline CCSR-NIES & $\begin{array}{c}\text { Climate System Research/National Institute for } \\
\text { Environmental Studies, Japan }\end{array}$ \\
\hline HadCM2 & Climate Model of Hadley's Centre, UK \\
\hline BCCR & Bjerknes Center for Climate Research, Norway \\
\hline cCCma & $\begin{array}{l}\text { Canadian Center for Climate Modeling and } \\
\text { Analysis, Canada }\end{array}$ \\
\hline AOM & Goddard Institute of Space Studies, USA \\
\hline CNRM & $\begin{array}{l}\text { Center National de Recherchers } \\
\text { Meteorologiques, France }\end{array}$ \\
\hline CM 3.0 & Institute for Numerical Mathematics, Russia \\
\hline $\begin{array}{l}\text { CSIRO-MK } \\
\quad 3.0\end{array}$ & $\begin{array}{l}\text { Australia's Commonwealth Scientific and } \\
\text { Industrial Research Organization, Australia }\end{array}$ \\
\hline $\begin{array}{l}\text { ECHAMS5- } \\
\text { OM }\end{array}$ & Max- Planck Institute for Meteorology, Germany \\
\hline ECHO-G & $\begin{array}{c}\text { Meteorological Research Institute of KMA, } \\
\text { Korea }\end{array}$ \\
\hline BCC-CM 1 & Beijing Climate Centre, China \\
\hline SXG 2005 & $\begin{array}{l}\text { National Institute of Geophysics and } \\
\text { Volcanology, Italy }\end{array}$ \\
\hline
\end{tabular}

Table 1: Some of the GCMs and originating institutions (Gautam 2010)

For example, the Center for Climate System Research of the National Institute for Environmental Studies (CCSR-NIES), located in Japan, operates a GCM covering an area of 5.50 latitude and 5.6250 longitude (Gautam 2010).

Lal (2001) used A-O GCM of the CCSR/NIES, Japan with A1, A2, B1 and B2 scenarios to project the temperature and rainfall trend over the inland regions of the Indian sub-continent. He found that the mean surface temperature may rise between $3.5^{\circ} \mathrm{C}$ and $5.5^{\circ} \mathrm{C}$ by 2080 . He concluded that the increase in annual mean precipitation over the Indian sub-continent is projected to be 7 to $10 \%$ by 2080 s. The seasonal projection of temperature and rainfall identified by Lal (2001) has been given in Table 2.

\begin{tabular}{|c|c|c|c|}
\hline \multicolumn{2}{|c|}{ Projected years } & $\begin{array}{c}\text { Increase in } \\
\text { temperature }\left({ }^{\circ} \mathrm{c}\right)\end{array}$ & $\begin{array}{c}\text { Change in } \\
\text { rainfall }(\%)\end{array}$ \\
\hline 2020s & Annual & $1.00-1.41$ & $2.16-5.97$ \\
\cline { 2 - 4 } & Winter & $1.08-1.54$ & $(-) 1.95-4.36$ \\
\cline { 2 - 4 } & Monsoon & $0.87-1.17$ & $1.81-5.10$ \\
\hline 2050s & Annual & $2.23-2.27$ & $5.36-9.34$ \\
\cline { 2 - 4 } & Winter & $2.54-3.18$ & $(-) 9.22-3.82$ \\
\cline { 2 - 4 } & Monsoon & $1.81-2.37$ & $7.18-10.52$ \\
\hline 2080s & Annual & $3.53-5.55$ & $7.48-9.90$ \\
\cline { 2 - 4 } & Winter & $4.14-6.31$ & $(-) 24.83-4.50$ \\
\cline { 2 - 4 } & Monsoon & $2.91-4.62$ & $10.10-15.18$ \\
\hline
\end{tabular}

Table 2: Climate change projections for the Indian sub-continent (Lal 2001)

\section{Methods of Downscaling}

Downscaling is a process of the development of climate data for a particular point or limited area, based on GCM simulation. Regional climate data may originate either from climate models or observations. Downscaling is required because GCMs, used in assessing climate change impacts, often operate on a coarse scale, and thus results obtained from GCMs are not immediately applicable in a smaller scale.

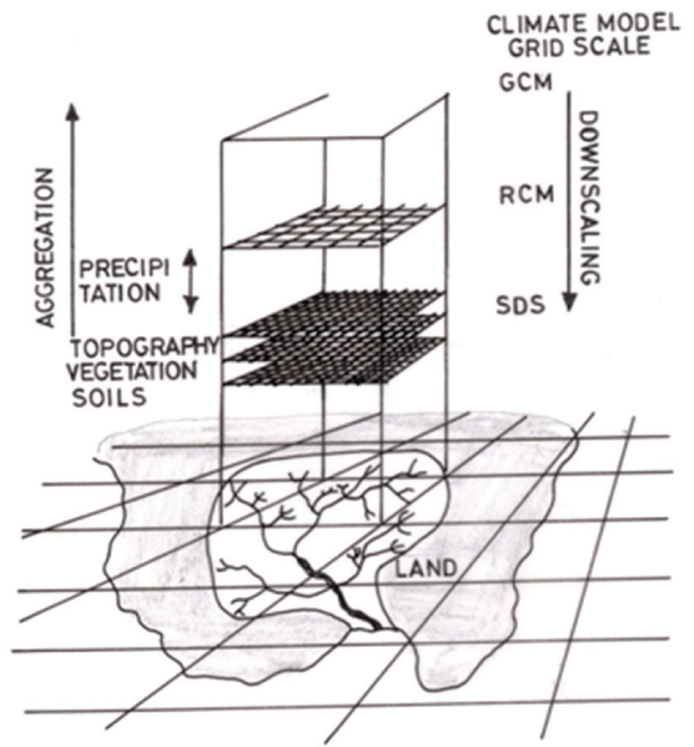

Figure 1: Illustrating the general approach to downscaling (Wilby and Dawson 2007)

In the Indian subcontinent, a limited number of studies have been conducted on downscaling of GCMs at the basin level. Tripathi et al. (2006) conducted a study of precipitation for a climate change scenario in entire India. The y performed downscaling of GCM output throughout India. They concluded that precipitation is projected to increase in most parts of the country based on the simulations of global oceanatmosphere coupled GCM (CGCM2) model under the IPCC 1992a (IS92a) scenario.

Ghosh and Mujumdar (2007) used statistical downscaling of GCM to simulate stream flow for the Mahanadi River basin in India. Their study showed a 
decreasing trend in monsoon stream flow of Mahanadi.

Gautam et al. (2012) performed statistical downscaling of GCM outputs for predicting the rainfall and runoff patterns in Satluj River basin, India. They have projected the future rainfall of 2030, 2050 and 2080 and found that the future rainfall will highly decrease for winter season compared to other seasons. In annual scale, they used Mann-Kendall test to identify the trend of the observed and predicted precipitation, temperature and discharge but they did not find any significant trend at 5\% significance level on above mentioned variables.

Gordon et al. (1992) looked at changes in the frequency distribution of simulated daily rainfall. They found that return periods (between 3 months and 5 years in this study) for CSIRO 4 GCM-simulated heavy rain events decreased by factors ranging from 2 to 5 under $2 \times \mathrm{CO} 2$ conditions in the locations they examined (i.e. India, Australia, Midwest USA and Europe).

Stapleton and Gangopadhyay (2011) applied nonparametric statistical downscaling approach to identify climate change scenario at Rohini River basin Nepal. They used the non-parametric statistical downscaling methodology for the precipitation data of 1976-2006. They have concluded that such kind of downscaling methodology is well-suited to the data poor situations for climate change projections.

Hence, all these studies have shown that downscaling can be used to model the hydrologic variables to assess the impact of climate change on hydrology. Application of this approach has been rising in recent years for the assessment of climate change impacts at local level. Basically there are two downscaling techniques available for the outcome of GCMs or regional circulation models (RCMs): Dynamical downscaling and statistical downscaling.

\section{Dynamical Downscaling}

Dynamical downscaling involves the nesting of a higherresolution RCM within a coarser- resolution GCM. RCMs use GCMs to define time-varying atmospheric boundary conditions, in which the physical dynamics of the atmosphere are modeled by using a horizontal grid spacing of 20-50 km (Mujumdar et al. 2009).

One of the strong features of dynamical downscaling is that it can resolve smaller-scale atmospheric features such as orographic precipitation. Complicated in design, inflexible in practical use and high computational cost are some drawbacks associated with dynamic downscaling, and due to these drawbacks it is not highly applicable to climate change impact studies (Mujumdar et al. 2009).

\section{Statistical Downscaling}

Statistical downscaling gives quantitative relationships between large-scale atmospheric variables (predictors) and local surface variables (predictants) (Wilby et al. 2004). Generally there are three inherent assumptions associated with statistical downscaling. Predictors are realistically modeled by a host GCM, empirical relationships are valid under altered climatic conditions, and predictors fully represent climate change signals (Ghosh and Mujumdar 2007).

Statistical downscaling techniques can be classified into three broad categories described shortly as follows (Wilby et al. 2004).

Weather generators: Statistical models of generating artificial weather variables with the same statistical characteristics as observations.

Weather typing: Grouping of local meteorological variables in relation to different classes of atmospheric circulations.

Transfer function: A regression-based method often used in downscaling.

Choice of predictor variables and empirical transfer schemes affect results to be obtained by using statistical downscaling. However, there are practical advantages of statistical downscaling compared to dynamical downscaling. For example, low-cost and rapid assessments of localized climate change impacts.

\section{Conclusions}

This study has signified importance of GCMs along with downscaling techniques. The study highlighted the practical application of GCMs and their use in the research of climate change with special reference to Indian subcontinent. This study made known some of the results obtained from different studies by means of GCMs carried out in the South Asian region including Nepal. Last but not the least, the application of GCMs and the downscaling technique can fill up the gap existing between large-scale (GCM level) and localscale (basin level) variables.

Narayan P. Gautam has been working as a faculty of Hydrology and Meteorology in Tribhuvan University, Kathmandu, Nepal. He has carried out research works in the fields of discharge analyses, climate change, precipitation analyses and so on. He has published numbers of papers and articles in different journals, magazines along with newspapers.

Corresponding address:ngautam33@gmail.com

Dr. Manohar Arora has been working as a scientific officer in National Institute of Hydrology, Roorkee, India. He has vast experience of research works in the fields of climate change and water resources.

\section{Email:arora@nih.ernet.in}

\section{References}

Gautam, N. P., Arora, M., Goel, N.K., Kumar A.R. S., 2012. Investigating the impact of climate change on future runoff of river Satluj. Journal of Hydrology 
and Meteorology, Vol. 8, No. 1.

Gautam, N.P., 2010. Climate change scenario generation using statistical downscaling. M. Tech. dissertation, Submitted in Indian Institute of Technology-Roorkee, Roorkee, India.

Gautam, N.P., 2014. Impacts of climate change as evident in the Langtang catchment. Hydro Nepal: Journal of Water, Energy and Environment, No. 15.

Ghosh, S., Mujumdar, P.P., 2007. Statistical downscaling of GCM simulations to streamflow using relevance vector machine. Advances of Water Resources 31: 132-146.

Gordon, H.B., Whetton, P.H., Pittock, A.B., Fowler, A.M., Haylock, M.R., 1992. Simulated changes in daily rainfall intensity due to the enhanced greenhouse effect: implications for extreme rainfall events, Clim. Dyn., Vol. 8, 83-102.

ICIMOD, 2009. Climate change in the Himalayas. International Centre for Integrated Mountain Development, information sheet 3, Kathmandu, Nepal.

IPCC, 2001. Climate Change 2001: Impacts, Adaptation, and Vulnerability [McCarthy, J.J., Canziani, O.F., Leary, N.A., Dokken D. J. ,Avid White K.S. (eds)], Cambridge University Press, Cambridge, UK.

IPCC, 2008. Climate change and water. Technical paper of the Intergovernmental Panel on Climate Change [Bates, B.C., Kundzew, Z.W., Wu, S., Palutikof, J.P.(eds.)]. IPCC Secretariat, Geneva, 210pp.

IPCC, 2009. http:// www. ipcc-data.org/index.html. Accessed 30 August 2009.

Lal, M., 2001. Climatic change- Implications for India's water resources, Journal of Indian Water Resources Society, Vol. 21, 101-119.

Mujumdar, P.P., Kumar, N.D., Srinivas, V.V., 2009. Assessment of water resources under climate change scenarios at river basin scale. Department of Civil Engineering, Indian Institute of Science, Banglore 560012.
Piechota, T.C., Garbrecht, J.D., 2006. Climate variability and climate change. Environmental and Water Resources, Institute of the American Society of Civil Engineers, United States of America, 3-18.

Solomon, S., Qin, D., Manning, M., Alley, R.B., Berntsen, T., Bindoff, N.L., Chen, Z., Chidthaisong, A., Gregory JM, Hegerl GC, Heimann M, Hewitson B, Hoskins BJ, Joos F, Jouzel J, Kattsov V, Lohmann U, Matsuno T, Molina M, Nicholls N, Overpeck J, Raga G, Ramaswamy V, Ren J, Rusticucci M, Somerville R, Stocker TF, Whetton, P., Wood, R.A., Wratt, D., 2007. Technical summary, In Climate Change 2007: The Physical Science Basis, Contribution of Working Group I to the Fourth Assessment Report of the Intergovernmental Panel on Climate Change, [Solomon S, Qin D, Manning M, Chen Z, Marquis M, Averyt KB, Tignor M, Miller HL (eds)]. Cambridge University Press: Cambridge and New York; $1-5$.

Sr. Pielke, R.A., Marland, G., Betts, R.A., Chase, T.N., Eastman, J.L., Niles, J.O., Niyogi, D.D.S., Running, S.W., 2002. The influence of land-use change and land scape dynamics on the climate system: relevance to climate change policy beyond the radiative effects of greenhouse gases. The Royal Society, 10.1098/rsta. 2002.1027.

Stapleton, S.O., Gangopadhyay, S., 2011. A nonparametric, statistical algorithm applied to the Rohini River basin, Nepal. Theor Appl Climatol 103:375-386. Doi 10.1007/s00704-010-0301-z.

Tripathi, S., Srinivas, V.V.,Nanjundiah, R.S., 2006. Downscaling of precipitation for climate change scenarios: A Support Vector Machine approach. The journal of hydrology 330(3-4): 621-640.

Wilby, R.L., Dawson, C.W., 2007. SDSM - A decision support tool for the assessment of regional climate change impacts.

Wilby, R.L., Charles, S.P., Zorita, E., Timbal, B., Whetton, P., Mearns, L.O., 2004. Guidelines for use of climate scenarios developed from statistical downscaling methods. Supporting material of the inter-governmental panel on climate change. 